\title{
Front Matter: Volume 6584
}

, "Front Matter: Volume 6584," Proc. SPIE 6584, Adaptive Optics for Laser Systems and Other Applications, 658401 (1 June 2007); doi: 10.1117/12.746904

SPIE Event: International Congress on Optics and Optoelectronics, 2007, Prague, SPIE. Czech Republic 


\title{
PROCEEDINGS OF SPIE
}

\section{Adaptive Optics for Laser Systems and Other Applications}

\author{
Gilles Cheriaux \\ Chris J. Hooker \\ Michal Stupka \\ Editors
}

18-19 April 2007

Prague, Czech Republic

Sponsored by

SPIE Europe

Cooperating Organizations

SPIE Czech Regional Chapter

COST

ESF-European Science Foundation (France)

Czech and Slovak Society for Photonics

ePIXnet (Belgium)

Fyzikálni Ústav (Czech Republic)

Meta Morphose (United Kingdom)

NEMO_Network of Excellence in Micro-Optics (Belgium)

PhOREMOST

SPIE Poland Chapter

Published by

SPIE 
The papers included in this volume were part of the technical conference cited on the cover and title page. Papers were selected and subject to review by the editors and conference program committee. Some conference presentations may not be available for publication. The papers published in these proceedings reflect the work and thoughts of the authors and are published herein as submitted. The publisher is not responsible for the validity of the information or for any outcomes resulting from reliance thereon.

Please use the following format to cite material from this book:

Author(s), "Title of Paper," in Adaptive Optics for Laser Systems and Other Applications, edited by Gilles Cheriaux, Chris J. Hooker, Michal Stupka, Proceedings of SPIE Vol. 6584 (SPIE, Bellingham, WA, 2007) Article CID Number.

ISSN 0277-786X

ISBN 9780819467126

Published by

SPIE

P.O. Box 10, Bellingham, Washington 98227-0010 USA

Telephone +1 3606763290 (Pacific Time) · Fax +1 3606471445

SPIE.org

Copyright (c) 2007, Society of Photo-Optical Instrumentation Engineers

Copying of material in this book for internal or personal use, or for the internal or personal use of specific clients, beyond the fair use provisions granted by the U.S. Copyright Law is authorized by SPIE subject to payment of copying fees. The Transactional Reporting Service base fee for this volume is $\$ 18.00$ per article (or portion thereof), which should be paid directly to the Copyright Clearance Center (CCC), 222 Rosewood Drive, Danvers, MA 01923. Payment may also be made electronically through CCC Online at copyright.com. Other copying for republication, resale, advertising or promotion, or any form of systematic or multiple reproduction of any material in this book is prohibited except with permission in writing from the publisher. The CCC fee code is $0277-786 \mathrm{X} / 07 / \$ 18.00$.

Printed in the United States of America.

Publication of record for individual papers is online in the SPIE Digital Library.

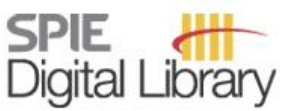

SPIEDigitalLibrary.org

Paper Numbering: Proceedings of SPIE follow an e-First publication model, with papers published first online and then in print and on CD-ROM. Papers are published as they are submitted and meet publication criteria. A unique, consistent, permanent citation identifier (CID) number is assigned to each article at the time of the first publication. Utilization of CIDs allows articles to be fully citable as soon they are published online, and connects the same identifier to all online, print, and electronic versions of the publication. SPIE uses a six-digit CID article numbering system in which:

- The first four digits correspond to the SPIE volume number.

- The last two digits indicate publication order within the volume using a Base 36 numbering system employing both numerals and letters. These two-number sets start with 00, 01, 02, 03, 04, 05, $06,07,08,09,0 A, 0 B \ldots 0 Z$, followed by 10-1Z, 20-2Z, etc.

The CID number appears on each page of the manuscript. The complete citation is used on the first page, and an abbreviated version on subsequent pages. Numbers in the index correspond to the last two digits of the six-digit CID number. 


\section{Contents}

vii Conference Committee

ix Introduction

Liquid crystalline nonlinear optical metamaterials with low-loss tunable negative-zeropositive refractive indices (Plenary Paper) [6587-203]

I. C. Khoo, A. Diaz, D.-H. Kwon, D. H. Werner, Pennsylvania State Univ. (USA)

\section{SESSION 1 HIGH-POWER LASER SYSTEM ADAPTIVE OPTICS}

658402 Adaptive optics at the PHELIX laser (Keynote Paper) [6584-01]

H.-M. Heuck, U. Wittrock, Münster Univ. of Applied Sciences (Germany); J. Fils, S. Borneis, K. Witte, U. Eisenbart, D. Javorkova, V. Bagnoud, S. Götte, A. Tauschwitz, E. Onkels,

Gesellschaft für Schwerionenforschung mbH (Germany)

658403 Design principle and first results obtained on the LMJ deformable mirror prototype (Invited Paper) [6584-02]

C. Grosset-Grange, J.-N. Barnier, C. Chappuis, H. Cortey, CEA Cesta (France)

658404 Wavefront correction and aberrations pre-compensation in the middle of Petawatt-class CPA laser systems [6584-03]

F. Canova, L. Canova, A. Flacco, R. Clady, J.-P. Chambaret, Lab. d'Optique Appliquée, CNRS, ENSTA-Ecole Polytechnique (France); F. Plé, M. Pittman, Lab. d'interaction du rayonnement $X$ avec la matière (France); T. A. Planchon, Colorado School of Mines (USA); M. Silva, R. Benocci, G. Lucchini, D. Batani, Univ. Milano-Bicocca (Italy); E. Lavergne,

G. Dovillaire, X. Levecq, Imagine Optic (France)

658405 Monomorph large aperture adaptive optics for high peak-power femtosecond lasers [6584-04]

G. Cheriaux, J.-P. Rousseau, F. Burgy, Lab. d'Optique Appliquée, CNRS, ENSTA, Ecole

Polytechnique (France); J.-C. Sinquin, J.-M. Lurçon, C. Guillemard, CILAS (France)

\section{SESSION 2 ASTRONOMICAL ADAPTIVE OPTICS AND APPLICATIONS}

658407 Review of astronomical adaptive optics systems and plans (Invited Paper) [6584-06]

N. Devaney, National Univ. of Ireland, Galway (Ireland)

658408 Optical wavefront differentiation: wavefront sensing for solar adaptive optics based on a LCD [6584-07]

D. Schmidt, O. von der Lühe, Kiepenheuer Institut für Sonnenphysik (Germany)

658409 High order optical aberrations influence to precision of astronomical image data processing [6584-08]

M. Řeřábek, P. Páta, Czech Technical Univ. in Prague (Czech Republic); P. Koten, Astronomical Institute (Czech Republic) 
6584 OA Surface tension determination using liquid sample micromirror property [6584-09]

J. Hošek, Czech Technical Univ. in Prague (Czech Republic)

6584 OB Symmetry descriptors for Si wafer characterisation for scanning helium atomic beam microscopy mirror [6584-10]

J. Galas, D. Litwin, S. Sitarek, Institute of Applied Optics (Poland); B. Surma, B. Piątkowski, Institute of Electronic Materials Technology (Poland)

6584 OD Smart lens: tunable liquid lens for laser tracking [6584-12]

F.-Y. Lin, National Tsing Hua Univ. (Taiwan); L.-Y. Chu, National Chiao Tung Univ. (Taiwan);

Y.-S. Juan, National Tsing Hua Univ. (Taiwan); S.-T. Pan, S.-K. Fan, National Chiao Tung Univ. (Taiwan)

$6584 \mathrm{OE}$ Wave front generation using a phase-only modulating liquid-crystal-based micro-display with HDTV resolution [6584-13]

A. Hermerschmidt, S. Osten, S. Krüger, HoloEye Photonics AG (Germany); T. Blümel, FISBA OPTIK GmbH (Germany)

6584 OF Adaptive optics system to accurately measure highly aberrated wavefronts [6584-14] M. Ares, S. Royo, Technical Univ. of Catalunya (Spain)

6584 OG Tunable electro-optical lithium niobate phase array for wavefront modulators [6584-15] M. Paturzo, P. Ferraro, Istituto Nazionale di Ottica Applicata, CNR (Italy); S. De Nicola, Istituto di Cibernetica, CNR (Italy); P. De Natale, Istituto Nazionale di Ottica Applicata, CNR (Italy); G. Pierattini, Istituto di Cibernetica, CNR (Italy)

\section{SESSION 4 LASER SYSTEM ADAPTIVE OPTICS SIMULATIONS AND APPLICATIONS}

$6584 \mathrm{OH} \quad$ Generation of $1.2 \mathrm{X}$ diffraction-limited focal spot from the $100 \mathrm{TW}$ Ti:sapphire laser system (Invited Paper) [6584-22]

T. M. Jeong, I. W. Choi, N. Hafz, J. H. Sung, D.-K. Ko, J. Lee, Gwangju Institute of Science and Technology (South Korea)

$6584 \mathrm{Ol}$ Computational model for time development of the EM field in pulsed laser systems [6584-18]

D. Škrabelj, Fotona (Slovenia); M. Marinček, Fotona (Slovenia) and Jozef Stefan Institute (Slovenia); I. Drevenšek-Olenik, Univ. of Ljubljana (Slovenia) and Jozef Stefan Institute (Slovenia); M. Leskovar, Fotona (Slovenia); M. Čopič, Univ. of Ljubljana (Slovenia) and Jozef Stefan Institute (Slovenia)

\section{POSTER SESSION}

6584 OM Target alignment on the LIL laser facility [6584-23]

M. Mangeant, J.-L. Dubois, R. André, P. Dupont, V. Moreau, C. Lissayou, C. Lanternier, E. Bar, S. Devaure, A. Perrin, P. Auliac, Y. Schiano, Commissariat à l'Energie Atomique (France) 
6584 ON Time fiducial on the LIL facility at CEA/CESTA [6584-24]

Y. Schiano, E. Bar, A. Richard, C. Feral, P. Darquey, Commissariat à l'Énergie Atomique (France)

Author Index 
Downloaded From: https://www.spiedigitallibrary.org/conference-proceedings-of-spie on 26 Apr 2023

Terms of Use: https://www.spiedigitallibrary.org/terms-of-use 


\title{
Conference Committee
}

\author{
Symposium Chairs
}

Pavel Tománek, Brno University of Technology (Czech Republic)

Miroslav Hrabovský, Palacký University (Czech Republic)

Hugo Thienpont, Vrije Universiteit Brussel (Belgium)

Symposium Honorary Chair

Karel Jungwirth, Institute of Physics (Czech Republic)

Conference Chairs

Gilles Cheriaux, École Nationale Supérieure de Techniques Avancées

(France)

Chris J. Hooker, Rutherford Appleton Laboratory (United Kingdom)

Michal Stupka, Institute of Physics (Czech Republic)

Conference Cochair

Petr Škoda, Astronomical Institute Ondrejov (Czech Republic)

Program Committee

Andrianto Handojo, Bandung Institute of Technology (Indonesia)

Hans-Martin Heuck, Münster University of Applied Sciences (Germany)

Pavel Homer, Institute of Physics (Czech Republic)

Jan Hošek, Czech Technical University in Prague (Czech Republic)

Michaela Kozlova, Institute of Physics (Czech Republic)

J. Larsson, Lunds Tekniska Högskola (Sweden)

Antonin Mikš, Czech Technical University in Prague (Czech Republic)

Jiri Novák, Czech Technical University in Prague (Czech Republic)

Ralf Nyholm, Lund University (Sweden)

Jaroslav Rehácek, Palacký University (Czech Republic)

P. Severova, Institute of Physics (Czech Republic)

\section{Session Chairs}

1 High-Power Laser System Adaptive Optics

Chris J. Hooker, Rutherford Appleton Laboratory (United Kingdom)

2 Astronomical Adaptive Optics and Applications

Petr Škoda, Astronomical Institute Ondrejov (Czech Republic) 
3 Wavefront Generation, Beam Shaping, and Measuring Techniques Gilles Cheriaux, École Nationale Supérieure de Techniques Avancées (France)

$4 \quad$ Laser System Adaptive Optics Simulations and Applications Michal Stupka, Institute of Physics (Czech Republic) 


\title{
Introduction
}

We are pleased to present the proceedings of the SPIE conference on Adaptive Optics for Laser Systems and Other Applications, held in the city of Prague in the Czech Republic in April 2007. There are few subjects where there is such a range of topics that can be covered under one general heading, but adaptive optics is certainly one of those subjects. As the title suggests, this conference was slanted toward the use of adaptive optics in laser systems, but the committee were delighted to receive many high-quality contributions from workers in other areas. Consequently, it was possible to compare the applications of the technology in many disciplines, identify common ground, and to learn new ideas from one another. The papers presented at the conference ranged from astronomy, which was the original inspiration for the development of adaptive optics technology and which continues to drive it to this day, through applications in high-powered lasers that are breaking new ground in attaining the highest energy densities, to subtle techniques involved in the measurement of important physical parameters and to innovative techniques in ophthalmic medicine. A number of papers on simulations and modelling of phase correction of optical beams made up the balance of contributions and completed a well-rounded conference.

We would like to thank the members of the programme committee for their hard work in recruiting and encouraging contributors and for assessing all the submissions, and the authors and presenters of the papers for their contributions to an interesting and highly enjoyable conference.

\author{
Michal Stupka \\ Gilles Cheriaux \\ Chris Hooker
}


Downloaded From: https://www.spiedigitallibrary.org/conference-proceedings-of-spie on 26 Apr 2023

Terms of Use: https://www.spiedigitallibrary.org/terms-of-use 